\title{
The Author Reply: Effect of Sperm DNA Fragmentation on Embryo Quality in Normal Responder Women in IVF and ICSI
}

\author{
Su Mi Kim ${ }^{1,2}$, Seul Ki Kim², Byung Chul Jee ${ }^{2,3}$, and Seok Hyun Kim² \\ ${ }^{1}$ Department of Obstetrics and Gynecology, Chungbuk National University Hospital, Cheongju; \\ ${ }^{2}$ Department of Obstetrics and Gynecology, Seoul National University College of Medicine, Seoul; \\ ${ }^{3}$ Department of Obstetrics and Gynecology, Seoul National University Bundang Hospital, Seongnam, Korea.
}

Dear Editor,

Thank you for your letter containing valuable comments regarding our paper.

We fully recognize the shortcomings of our paper that were pointed out (retrospective design, small sample size). We apologize for having a small number of cases; if there were more cases, it would have been possible to analyze them except for the male factor infertility. Male factor infertility is usually diagnosed by the conventional semen analysis, but semen from men with male factor infertility may show variable sperm DNA fragmentation (SDF) level. Here, we just wanted to see if the embryo quality differs by SDF levels, regardless of the diagnosis of infertility.

Although the current SDF testing methods have several advantage and disadvantages, we still have a lot of experience with Halosperm assay, and have published many related papers..$^{1-4}$ The problem of Halosperm assay itself is that we cannot help it, but we are building data by standardizing Halosperm assay through many experiences. We believe that better information can be provided by applying various SDF testing methods to semen samples.

\section{ORCID iDs}

Su Mi Kim https://orcid.org/0000-0002-5236-7184

Seul Ki Kim https://orcid.org/0000-0002-1647-6711

Byung Chul Jee https://orcid.org/0000-0003-2289-6090

Seok Hyun Kim https://orcid.org/0000-0003-0649-3224

\section{REFERENCES}

1. Kim SW, Jee BC, Kim SK, Kim SH. Sperm DNA fragmentation and sex chromosome aneuploidy after swim-up versus density gradient centrifugation. Clin Exp Reprod Med 2017;44:201-6.

2. Choi HY, Kim SK, Kim SH, Choi YM, Jee BC. Impact of sperm DNA fragmentation on clinical in vitro fertilization outcomes. Clin Exp Reprod Med 2017;44:224-31.

3. Lee D, Jee BC. Evaluation of normal morphology, DNA fragmentation, and hyaluronic acid binding ability of human spermatozoa after using four different commercial media for density gradient centrifugation. Clin Exp Reprod Med 2019;46:8-13.

4. Kim SW, Nho EJ, Lee JY, Jee BC. Specific tail swelling pattern in hypo-osmotic solution as a predictor of DNA fragmentation status in human spermatozoa. Clin Exp Reprod Med 2019;46:147-51.
Received: September 25, 2020 Accepted: September 26, 2020

Corresponding author: Byung Chul Jee, MD, PhD, Department of Obstetrics and Gynecology, Seoul National University Bundang Hospital, 82 Gumi-ro 173beon-gil, Bundang-gu, Seongnam 13620, Korea.

Tel: 82-31-787-7254, Fax: 82-31-787-4054, E-mail: blasto@snubh.org

-The authors have no potential conflicts of interest to disclose.

(C) Copyright: Yonsei University College of Medicine 2020

This is an Open Access article distributed under the terms of the Creative Commons Attribution Non-Commercial License (https://creativecommons.org/licenses/ by-nc/4.0) which permits unrestricted non-commercial use, distribution, and reproduction in any medium, provided the original work is properly cited. 